\title{
Temporal processing skills in people who stutter
}

Universidade Federal da Paraíba - UFPB, João Pessoa, Paraíba, Brasil.

2 Universidade Federal da Paraíba - UFPB, Curso de Fonoaudiologia, João Pessoa, Paraíba, Brasil.

3 Universidade Federal da Paraíba - UFPB, Departamento de Fonoaudiologia, João Pessoa, Paraíba, Brasil.

${ }^{4}$ Universidade Federal da Paraíba - UFPB, Departamento de Fisioterapia, Programa de Pós-Graduação em Neurociência Cognitiva e Comportamento, João Pessoa, Paraíba, Brasil.

Universidade Federal da Paraíba - UFPB, Departamento de Fonoaudiologia, Programa Associado de Pós-Graduação em Fonoaudiologia, Programa de PósGraduação em Linguística, João Pessoa, Paraiba, Brasil.

${ }^{6}$ Universidade Federal da Paraíba - UFPB, Departamento de Fonoaudiologia, Programa Associado de Pós-Graduação em Fonoaudiologia, Programa de PósGraduação em Neurociência Cognitiva e Comportamento, João Pessoa, Paraíba, Brasil.

Conflict of interests: Nonexistent

\section{(c) (i)}

Received on: April 28, 2020

Accepted on: February 26, 2021

Corresponding address:

Marine Raquel Diniz da Rosa

Universidade Federal da Paraíba, Centro

de Ciências da Saúde Departamento de

Fonoaudiologia

Cidade Universitária - Campus I -

Castelo Branco

CEP: 58051-900 - João Pessoa, Paraíba,

Brasil

E-mail:mrdrosa@yahoo.com.br
Thaís Nunes Machado Ferreira1 https://orcid.org/0000-0002-6107-4172

Larissa Roberta Pereira Rodrigues ${ }^{2}$ https://orcid.org/0000-0002-8947-2754

Débora Vasconcelos Correia ${ }^{3}$ https://orcid.org/0000-0001-5839-2738

Suellen Mary Marinho dos Santos Andrade ${ }^{4}$ https://orcid.org/0000-0002-6801-0462

Giorvan Anderson dos Santos Alves ${ }^{5}$ https://orcid.org/0000-0003-1619-0139

Marine Raquel Diniz da Rosa ${ }^{6}$ https://orcid.org/0000-0003-0920-2234

\section{ABSTRACT}

Purpose: to investigate the auditory skills of temporal resolution and ordering in people who stutter.

Methods: an observational, cross-sectional, analytical, and comparative research between study and control groups conducted at a speech-language-hearing teaching clinic of an academic institution, comprising people who stutter (who attended a public outreach program) and volunteers without communicative disorders, for 13 months. The procedures used were auditory perception anamnesis, acoustic immittance, and pure-tone and speech audiometry to discharge hearing changes. The participants who met the eligibility criteria had their resolution and ordering skills assessed with the Gaps-in-Noise, Random Gap Detection, Pitch Pattern Sequence, and Duration Pattern Sequence tests and the data obtained were entered into a spreadsheet for descriptive and inferential statistical analyses.

Results: the study group presented changes in temporal resolution and ordering. A statistically significant difference was also verified comparing the assessment findings of the study and control groups, in all the assessment tests.

Conclusion: temporal resolution and ordering changes were observed in the people presented with stuttering, regardless of sex or chronological age.

Keywords: Stuttering; Auditory Perception; Hearing; Speech Perception; Audiology; Speech 


\section{INTRODUCTION}

Oral communication is the interactive modality that predominates as a means to exchange experiences, share new knowledge, and put forth ideas, thoughts, desires, and aspirations. Fluency is an important skill in the development of the speaker's communication health. It is the continuous and smooth flow of speech that results from the harmonious neural processing integration between language and motor acts ${ }^{1}$.

The manner how auditory information is processed, especially when related to speech perception, is essential to understand possible expressive language difficulties, including stuttering ${ }^{2}$.

Childhood-onset fluency disorder is a change in the typical fluency pattern caused by excessive breaks (disfluencies) in speech production. Such breaks are involuntary and interfere with the main fluency parameters, namely: continuity, effort, and time taken to speak. Stuttering is associated with desynchronized neurolinguistic processes; hence such a person cannot avoid breaking the flow of speech. Stuttering is a multidimensional, complex, genetic, and neurofunctional disorder, whose etiologic factors are diversified and have a complex interaction. These characteristics affect the selection of assessment, diagnosis, and therapeutic procedures necessary to their care, as well as the clinical prognosis ${ }^{3}$.

The neurofunctional dynamics of stuttering involves biological factors, highlighting auditory temporal processing, which is the basis of auditory processing. Many auditory information characteristics are influenced by time - which is the converging point of the neurophysiological dynamics of hearing and fluency - because speech fluency involves the synchronic interaction between the acoustic aspects of speech production and perception linked in time $e^{4,5}$.

Temporal imprecision in speech perception may be closely related to the development of hearing and of disfluent speech, as pointed out by research ${ }^{4,5}$. Thus, central auditory processing assessment aims to investigate a set of specific auditory skills (on which the person depends to interpret what they hear) and neuroaudiological processes (temporality of sounds, rhythm, and prosody) involved in speech fluency processing. Such an assessment enables the identification of the Central Auditory Processing Disorder (CPAD), which occurs when there is a partial or total loss of the auditory image analysis function ${ }^{6-8}$.

The auditory temporal processing skills encompass temporal resolution, ordering, masking, and integration ${ }^{5,9}$. It processes the acoustic signal in relation to the time taken to receive, discriminate, or detect the stimuli presented in quick succession. It is one of the physiological mechanisms of the central auditory processing, being also related to speech perception considering that the characteristics of the auditory information are influenced by time $\mathrm{e}^{5,10}$.

The integration skill is the sum of the neuronal activities that cause a sound energy increase, both in duration and intensity of the stimulus. Temporal masking, in its turn, is the changed perception of sound due to the presence of another subsequent auditory stimulus. However, there are yet no validated clinical tools to assess such skills ${ }^{11}$. Therefore, they were not included in this study's investigation.

Temporal ordering refers to processing auditory stimuli in the order they occur, allowing the hearer to discriminate the correct sequence of sounds. This skill is often assessed with frequency and duration pattern tests, which are mainly used to analyze prosodic aspects of speech, such as rhythm, stress, and intonation. Hence, temporal ordering difficulties may contribute to disfluent speech ${ }^{5,7,12}$.

Temporal resolution is responsible for detecting quick changes in sound stimuli in as short a time as necessary to discriminate two acoustic stimuli. It is an important skill, necessary for accurate auditory processing and speech perception and development. It is assessed with gap detection tests $5^{5,12,13}$.

Studies have demonstrated a close relationship between auditory processing and stuttering, as the central auditory processing was changed in many people who stutter in various age groups. Some results indicated functional differences between the frontal and temporal regions of the brain related to speech perception, highlighting the unbalance present in the neural network involved in the speech perception tasks $2,6,9,10,14,15$.

Concerning the structural and functional aspects of the brain of people who stutter, studies with functional magnetic resonance imaging (MRI) found volumetric and microstructural differences in the brain regions associated with stuttering in the whole speech processing neural network. There were deficits in the regions and pathways related especially to the motor part of speech and the auditory function ${ }^{16-19}$.

Given the above, it is evident that changes in auditory temporal processing, particularly in temporal resolution and ordering, can also have consequences in speech fluency. Hence, this study aimed to investigate 
the auditory temporal resolution and ordering in people who stutter.

\section{METHODS}

This was an observational, cross-sectional, analytical study, with group comparisons. It was approved by the Ethics Committee of the Universidade Federal da Paraíba - UFPB (Federal University of Paraíba), Brazil, under number 2.413.862. All the participants signed the informed consent form. Data were collected between November 2016 and December 2017 at the SpeechLanguage-Hearing Teaching Clinic of the Universidade Federal da Paraíba.

The initial sample comprised 46 volunteers, of whom 12 participants with speech and/or hearing disorders were excluded. The participants that comprised the sample were divided into two groups: Study group (G1), diagnosed with stuttering before beginning the speech-language-hearing therapeutic process; and the control group (G2), without stuttering or any other speech and/or hearing disorder. The G1 inclusion criteria encompassed having normal bilateral auditory thresholds and type A tympanometric curve; having a speech-language-hearing diagnosis of stuttering; being 8 to 55 years old. As for G2, the inclusion criteria encompassed not having any speech or language disorder; having normal bilateral auditory thresholds and type A tympanometric curve; not being submitted to any speech-language-hearing therapy; and being 8 to 55 years old. All G2 participants were matched for age with $\mathrm{G} 1$.

The participants that did not agree voluntarily to participate in the research or, in the case of children, whose parents/guardians did not authorize their participation were excluded from the study in either G1 or G2. Those who had evident difficulties understanding the tests, not being able to perform them, were likewise excluded, as shown in Figure 1.

The final sample comprised 34 participants, 17 patients with stuttering, receiving care in the institution's public outreach program (G1), and 17 volunteers, children and university students without stuttering or any other speech and/or hearing disorder (G2). This group's sample was selected by convenience.

All the participants were submitted to the auditory perception anamnesis proposed by Pereira \& Schochat ${ }^{20}$, acoustic immittance, and pure-tone and speech audiometry. The anamnesis had questions related to the participants' auditory performance and how they behaved when exposed to noise. The

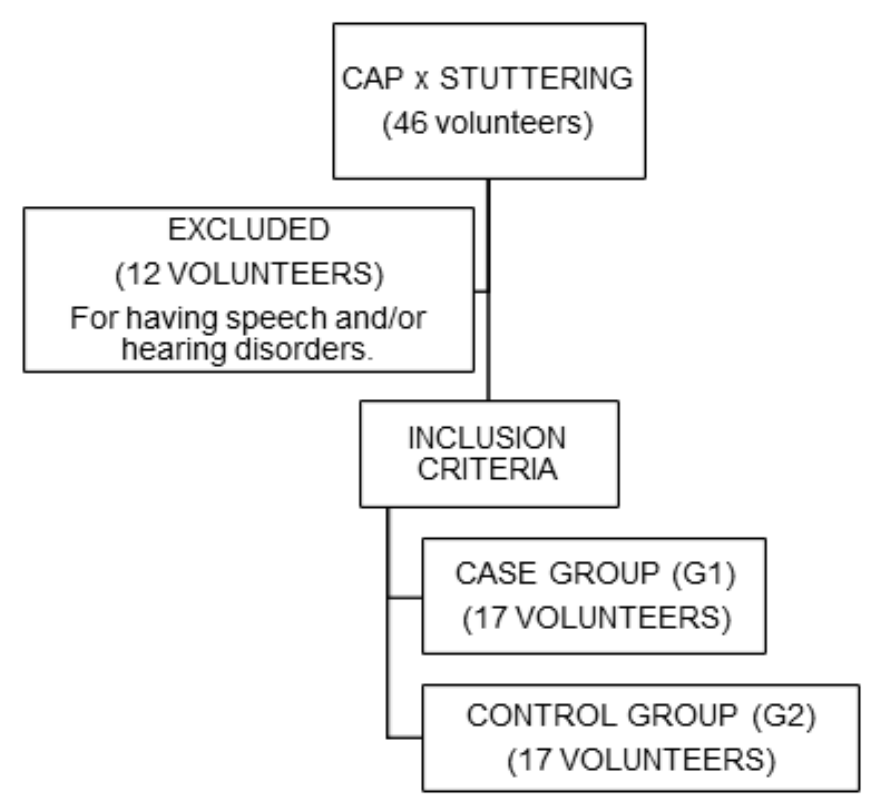

Caption: CAP $=$ Central Auditory Processing

Figure 1. Organizational chart of the research population

acoustic immittance aimed to investigate the middle ear status, verifying tympanic membrane complacency and contra- and ipsilateral acoustic reflexes at 500, 1000, 2000, and $4000 \mathrm{~Hz}$ (contralateral) and 1000 and 2000 $\mathrm{Hz}$ (ipsilateral). The participants with a type A tympanogram were apt to participate in the study.

The pure-tone and speech audiometry researched the auditory thresholds and speech intelligibility. The test was conducted in a sound booth, researching the frequencies of 250, 500, 1000, 2000, 3000, 4000,6000, and $8000 \mathrm{~Hz}$ (air-conduction) and 500, 1000, 2000, 3000 , and $4000 \mathrm{~Hz}$ (bone-conduction). This last one was performed only if the person had air-conduction auditory thresholds higher than $20 \mathrm{dBHL}$.

The volunteers that had symmetrical normal hearing, with a speech recognition percentage index (SRPI) greater than $70 \%$ and agreed to participate proceeded to the clinical outcome of the research - i.e., the assessment of the auditory temporal processing skills. The Auditec recordings (Saint Louis) were used to perform the Gaps-in-Noise test (GIN), Random Gap Detection Test (RGDT), Pitch Pattern Sequence test (PPS), and Duration Pattern Sequence test (DPS). All of them were conducted in a sound booth with two-channel equipment (which ensured the effectiveness of the central auditory processing tests) connected to an iPod manufactured by Apple.

The GIN aimed to analyze temporal resolution, as it is related to the minimum time required to segment or solve acoustic events ${ }^{21}$. It presents stimuli distributed 
into four test tracks and one training track, ensuring that the person understands the dynamics of the test. The task consists of presenting 6-second white noise segments, intercalated with random silence intervals (gaps). The volunteers were asked to raise their hands when they heard the gaps, aware that such intervals would have different durations. The shortest gap perceived in at least $67 \%$ of the presentations was considered the threshold 22 .

In the RGDT, also aiming to assess temporal resolution, the participant was instructed to identify the pairs of tones separated at intervals randomly ranging from 0 to $40 \mathrm{~ms}$. The tones were presented at 500, 1000,2000 , and $4000 \mathrm{~Hz}$, each one with nine paired pure-tone presentations at $50 \mathrm{dBSL}$. The person was expected to indicate whether they were hearing one or two tones. The normal standard considered for children were responses equal or inferior to $15 \mathrm{~ms}$, whereas for adults the normal responses were equal or inferior to $10 \mathrm{~ms}^{23}$.

In the PPS, which investigated temporal ordering, three successive tones were presented so that only one of them had a different frequency from the other two. In this task, the participant was asked to name and/or imitate the sounds as low- or high-pitched in the sequence they were presented. The results were considered normal when the percentage of correct answers was equal to or higher than $76 \%^{24}$. The three successive tones were presented binaurally, one of them at a different frequency - high-pitched: $1122 \mathrm{~Hz}$; low-pitched: $880 \mathrm{~Hz}$. Hence, six combinations were possible: HHL, LHL, LHH, HLH, HLL, and LLH.

In the DPS, also meant to assess temporal ordering, the volunteer should discriminate a sequence of three $1000 \mathrm{~Hz}$ sounds which had two different durations - two short sounds and a long one, or two long sounds and a short one. The short and long stimuli lasted respectively $250 \mathrm{~ms}$ and $500 \mathrm{~ms}$, whose sound intensity either increased or decreased for $10 \mathrm{~ms}$. This task had six different sequence patterns repeated 10 times, totaling 60 patterns. The minimum value considered a normal standard for the test was $70 \%$. The participant was asked to respond verbally what was the sound duration sequence (whether short or long) or imitate the sound types presented. As it does not use speech stimuli, it can be applied to language changes ${ }^{25}$.
Having carried out the abovementioned tests and investigated the auditory skills selected for assessment in this study, the resulting data were analyzed. They were entered into a spreadsheet for descriptive statistical analysis with absolute and relative frequency measures, mean and standard deviation. The inferential analysis used the Kolmogorov-Smirnov test to verify the normal distribution of the data (only the DPS did not have a normal distribution [ $p=0.02]$ ); the chi-square test, to verify associations between the groups and the presence of changes; Student's t-test, to analyze independent and parametric data; and the Mann-Whitney test, to analyze non-parametric data, comparing the mean results of $\mathrm{G} 1$ and $\mathrm{G} 2$ assessment tests. The R statistical software, version 2.11.0, was used, and the significance level was set at $5 \%$.

Of the volunteers who participated in the study, 52.9\% $(n=18)$ were males and $47.1 \%(n=16)$ were females. The mean age of the participants allocated in $\mathrm{G} 1$ was 22.35 ( \pm 10.48 ) years, while that of $\mathrm{G} 2$ was 22.53 ( \pm 10.54 ) years. There was no statistically significant difference between these means ( $p=0.961$ ), thus, confirming the homogeneity of the groups.

\section{RESULTS}

Table 1 presents the assessment data of the temporal resolution and ordering of the auditory processing of the people in G1 and G2. The GIN revealed that $88.2 \%(n=15)$ of the people who stutter obtained changed results in temporal resolution. It was likewise in the other tests, as the temporal resolution and ordering were changed in $70.6 \%(n=12)$ of $G 1$ in RGDT and PPS, respectively. In DPS, which investigated temporal ordering, the change occurred in $52.9 \%$ $(n=9)$ of the participants. It was also observed that, in all the tests, the G2 volunteers had normal results.

Hence, it was verified that the presence or absence of stuttering may be associated with changes in the auditory processing regarding temporal resolution and ordering. This is noticed in the significant difference in the compared findings of the groups' assessments, in all tests to which they had been submitted: GIN $(p=0.048)$, RGDT $(p=0.0001)$, PPS $(p=0.0001)$, and DPS $(p=0.001)$ (Table 1). 
Table 1. Assessment of the temporal processing skills in people with and without a diagnosis of stuttering

\begin{tabular}{|c|c|c|c|c|c|}
\hline \multirow{2}{*}{ Variables } & \multicolumn{2}{|c|}{ CASE GROUP } & \multicolumn{2}{|c|}{ CONTROL GROUP } & \multirow{2}{*}{ p-value } \\
\hline & $\mathbf{N}$ & $\%$ & $\mathbf{N}$ & $\%$ & \\
\hline \multicolumn{6}{|l|}{ GIN } \\
\hline Normal & 2 & 11.8 & 17 & 100 & \multirow{2}{*}{$0.048^{*}$} \\
\hline Changed & 15 & 88.2 & 0 & 0 & \\
\hline \multicolumn{6}{|l|}{ RGDT } \\
\hline Normal & 5 & 29.4 & 17 & 100 & \multirow{2}{*}{$0.0001 *$} \\
\hline Changed & 12 & 70.6 & 0 & 0 & \\
\hline \multicolumn{6}{|l|}{ PPS } \\
\hline Normal & 5 & 29.4 & 17 & 100 & \multirow{2}{*}{$0.0001^{*}$} \\
\hline Changed & 12 & 70.6 & 0 & 0 & \\
\hline \multicolumn{6}{|l|}{ DPS } \\
\hline Normal & 8 & 41.1 & 17 & 100 & \multirow{2}{*}{$0.001^{*}$} \\
\hline Changed & 9 & 52.9 & 0 & 0.0 & \\
\hline
\end{tabular}

Captions: GIN - Gaps-in-Noise; RGDT - Random Gap Detection Test; PPS - Pitch Pattern Sequence; DPS - Duration Pattern Sequence.

Chi-square test; significance * $p<0.05$. Source: João Pessoa, Brazil, 2017.

The comparison between the mean percentages of correct answers of both groups revealed a statistically significant difference in GIN ( $p=0.005)$, PPS $(p=$ $0.0001)$, and DPS $(p=0.001)$. In all of them, the people who stutter had a lower index of correct answers than G2 (Table 2).

Concerning the response time in GIN and RGDT, the people who stutter took longer to identify the intervals in between sounds, with a mean of $6.12( \pm$
2.93) in GIN and 17.64 ( \pm 8.99) in RGDT - this last one out of normal standards. In this case, statistically significant differences were also observed between the mean times of both groups in the temporal resolution $(p=0.006)$ and ordering test $(p=0.0001)$, restating that people who stutter are more susceptible to presenting changes in auditory temporal processing (Table 2).

Table 2. Mean percentage of correct responses and response time in temporal processing skill assessment tests in people with and without a diagnosis of stuttering

\begin{tabular}{lccccc}
\hline \multirow{2}{*}{ Variables } & \multicolumn{2}{c}{ CASE GROUP } & \multicolumn{2}{c}{ CONTROL GROUP } & \multirow{2}{*}{ p-value } \\
\cline { 2 - 4 } & Mean & SD & Mean & SD & \\
\hline GIN (ms) & 6.12 & 2.93 & 3.76 & 1.48 & $0.006^{*}$ \\
GIN (\%) & 67.99 & 18.38 & 83.82 & 10.87 & $0.005^{*}$ \\
RGDT (ms) & 17.64 & 8.99 & 5.86 & 2.63 & $0.0001^{*}$ \\
PPS (\%) & 65.62 & 20.66 & 86.67 & 7.03 & $0.0001^{*}$ \\
DPS (\%)* & 69.18 & 24.49 & 92.30 & 5.47 & $0.001^{*}$ \\
\hline
\end{tabular}

Captions: SD - standard deviation; GIN - Gaps-in-Noise; RGDT - Random Gap Detection Test; PPS - Pitch Pattern Sequence; DPS - Duration Pattern Sequence. Chi-square test; ${ }^{* *}$ Mann-Whitney test; significance ${ }^{*} p<0.05$. Source: João Pessoa, Brazil, 2017.

\section{DISCUSSION}

This study investigated how people who stutter process the acoustic signal in relation to time. Time can be perceived as a parameter that goes beyond speech production, visualizing its broader spectrum so as to encompass sound perception and discrimination. Hence, fluency is approached as a skill that, in order to maintain its synchronicity, needs to transit between communicative input and output in a bidirectional flow of information ${ }^{26}$.

The temporal processing is known to be the basis and physiological mechanism of central auditory processing. Hence, it is essential to apply tests involving temporal skills in people with complaints 
related to speech fluency. The literature points out that the auditory information characteristics are influenced by time, which is related to speech perception. It also states that central auditory processing difficulties lead to sound pattern interpretation difficulties. Consequently, information comprehension is impaired, causing behavioral changes $5,27,28$.

When an atypical neurophysiological pattern hinders the harmony necessary to link the sound sequences in speech production - as seen in people who stutter -, it must be considered that there is a neural implication responsible for causing the disfluent and broken speech. It may be likewise responsible for deficient auditory processing because both functions share the same brain structures ${ }^{14}$.

In this regard, research points to the anterior temporal region, which has part of the anterior commissure, as responsible for taking acoustic information or inhibit the impulses from one temporal lobe to the other. It also states that a lesion or disorder in the central auditory pathways and/or temporal lobe has consequences to the learning processes involved in organizing the person's phonological system and language $\mathrm{e}^{29-31}$.

All this evidence of atypical neurophysiological patterns involving hearing and fluency has also been observed regarding the auditory skill performance in people who stutter. This was perceived in their inferior temporal processing performance as compared with people without fluency changes. Difficulties acquiring or storing time-sequence information may contribute to disfluent speech production - which explains the low performance of people who stutter in tests assessing temporal ordering and resolution? ${ }^{7}$.

In this study, temporal resolution was the most changed auditory temporal processing skill. The literature describes this skill as allowing us to detect both quick changes in the sound stimulus and the shortest time interval necessary to discriminate two acoustic stimuli. This capacity to detect very quick temporal changes from one sound to another makes it possible to distinguish the different phonemes that make up speech - for instance, the slight changes between voiceless and voiced phonemes - since it is based on the length of the silence interval between the consonant and the vowel ${ }^{12,13,25,32}$.

Temporal ordering, in its turn, is the most assessed temporal processing skill in the studies found in academia. This skill refers to the auditory stimuli process in the order they take place. It enables the person to discriminate the correct occurrence of sounds regarding their duration and frequency, as well as changes in the flow of information between programing the speech motor plan and performing its movement $5,33-35$.

In clinical practice, RGDT is the most used test to assess temporal resolution, perhaps because it was developed first and is conducted faster than GIN although studies demonstrate some advantages of GIN regarding its application and the verification of results, which was clear in the present study ${ }^{12,13,36}$. Another piece of research compared the performance of children and adults in both tests (RGDT and GIN). After the comparative statistical analysis, they observed that the gap detection thresholds in the RGDT were significantly higher than those in GIN, corroborating the results obtained in this study ${ }^{37}$.

Comparing the sexes and the performance of normally hearing adults in RGDT and GIN, this study did not find any significant differences. However, other authors ${ }^{13}$ found significant differences between the sexes in the tests - in both of which the males had a better performance.

Regarding the same sample's higher thresholds obtained in the RGDT than in GIN, a supposition is that the RGDT parameters require the person to perform a more complex task, involving auditory fusion and temporal resolution - whereas GIN only tests temporal resolution. The RGDT needs a cognitively more complex response, in which the person is instructed to speak or gesture whether they perceived one or two stimuli. Differently, the GIN requires no more than a simple, nonverbal response, in which the person is expected to signal only when they notice the stimulus has been interrupted ${ }^{36}$.

The tests applied in the temporal ordering assessment (which refers to discriminating auditory stimuli in the order they happen) require the person's ability to correctly discriminate the sequence of sounds regarding their duration and frequency. The correct response in these tests demands short-term memorization of the three tones the person hears to then evocate them briefly. Since memory is present in auditory processing, then it is hypothesized that some people may have worse responses, not because they cannot discriminate the tone, but because they have memory difficulties. Concordantly, it has been stated that attention and short-term memory must be involved in the temporal ordering process ${ }^{11,37}$. 
Stuttering, with its impaired rhythm and the changes in suprasegmental processes of speech fluency, may be directly intertwined with the auditory temporal processing disorder found in G1. Temporal resolution and ordering tests applied in combination to assess auditory processing in research furnish the complementary investigation that stuttering needs - as it is a complex disorder with multiple interfaces and various cognitive skills and domains ${ }^{2,6}$.

Hence, investigating the ability to detect quick sound changes (temporal resolution) and discriminate sound sequences (temporal ordering) is relevant to the speech-language-hearing care of people who stutter and have other fluency disorders as well. Thus, identifying these clinical needs aids the diagnosis, intervention, and prognostic analysis of the case.

\section{CONCLUSION}

This study's results revealed changes in the temporal resolution and ordering of people who stutter, regardless of sex or chronological age. This study contributed to reinforce the importance of assessing the auditory temporal processing skills in the speechlanguage-hearing care of people with changes in fluency. It also points to the need for including therapeutic objectives and strategies to train these skills, aiming at results in the patient's communicative performance.

\section{REFERENCES}

1. Andrade CRFD, Juste F. Aplicação de um teste americano de severidade da gagueira (SSI) em crianças fluentes falante do Português Brasileiro. Pró-Fono R. Atual. Cientif. 2001;13(2):177-80.

2. Silva R, Oliveira CMC, Cardoso ACV. Aplicação dos testes de padrão temporal em crianças com gagueira desenvolvimental persistente. Rev. CEFAC [journal on the internet]. 2011 [accessed on 2017 Mar 14]; 13(5):902-8. Available at: http://www.scielo.br/scielo.php?script $=$ sci_ arttext\&pid=S1516-18462011000500015\&Ing=en. Epub June 03, 2011. https://doi.org/10.1590/ S1516-18462011005000045.

3. AMERICAN PSYCHIATRIC ASSOCIATION. Manual diagnóstico e estatístico de transtornos mentais. 4a ed. Porto Alegre: Artes Médicas, 1995.
4. Arcuri CF, Schiefer AM, Azevedo MF. Research about suppression effect and auditory processing in individuals who stutter. CoDAS [journal on the internet]. 2017 [accessed on 2017 Dec 7]; 29(3):e20160230. Available at: http://www.scielo. $\mathrm{br} /$ scielo.php? script $=$ sci_arttext \& $p i d=$ S2317$17822017000300312 \&$ Ing=en. Epub May 22, 2017. http://dx.doi.org/10.1590/2317-1782/20172016230.

5. Samelli AG, Schochat E. Processamento auditivo, resolução temporal e teste de detecção de gap: revisão da literatura. Rev. CEFAC [journal on the internet]. 2008 [accessed on $2017 \mathrm{Apr}$ 29]; 10(3):369-77. Available at: http://www.scielo. $\mathrm{br} /$ scielo.php? script $=$ sci_arttext $\&$ pid $=$ S1516$18462008000300012 \& \operatorname{lng}=$ en. $\quad$ https://doi. org/10.1590/S1516-18462008000300012.

6. Andrade AN, Gil D, Schiefer AM, Pereira LD. Processamento auditivo em gagos: análise do desempenho das orelhas direita e esquerda. Rev. soc. bras. fonoaudiol. [journal on the internet]. 2008 Mar [accessed on 2017 Mar 14]; 13(1):20-9. Available at: http://www.scielo. br/scielo. php?script $=$ sci_arttext $\&$ pid $=$ S151680342008000100006\&lng =en. https://doi.org/ 10.1590/S1516-80342008000100006.

7. Alvarez AMMA, Balen SA, Misorelli MIL, Sanchez ML. Processamento auditivo central: proposta de avaliação e diagnóstico diferencial. In: Munhoz MSL, Caovilla HH, Silva MLG, Ganança MM, editors. Audiologia clínica. São Paulo: Atheneu, 2000. v. 2. p. 103-20.

8. Prestes R, Andrade AN, Santos RBF, Marangoni AT, Schiefer AM, Gil D. Temporal processing and long-latency auditory evoked potential in stutterers. Braz. j. otorhinolaryngol. [journal on the internet]. $2017 \mathrm{Apr}$ [accessed on $2017 \mathrm{Dec}$ 7]; 83(2):142-6. Available at: http://www.scielo. br/scielo.php?script $=$ sci_arttext \&pid $=$ S180886942017000200142\&Ing=en. http://dx.doi.org/ 10.1016/j.bjorl.2016.02.015.

9. Mourão AM, Esteves CC, Labanca L, Lemos SMA. Desempenho de crianças e adolescentes em tarefas envolvendo habilidade auditiva de ordenação temporal simples. Rev. CEFAC [journal on the internet]. 2012 accessed on 2017 Dec 2]; 14(4):659-68. Available at: http://www.scielo.br/scielo.php?script $=$ sci_ arttext\&pid=S1516-18462012000400009\&lng =en. Epub Dec 13, 2011. https://doi.org/10.1590/ S1516-18462011005000141. 
10. Meyers SC, Hughes LF, Schoeny ZG. Temporalphonemic processing skills in adult stutterers and nonstutterers. $J$ Speech Hear Res. 1989;32(2):274-80.

11. Filippini R, Schochat E. A new paradigm for temporal masking assessment: pilot study. CoDAS [journal on the internet]. 2014 [accessed on 2017 Mar 25]; 26 (4):302-7. Available at: http://www. scielo.br/scielo.php?script =sci_arttext\&pid = S2317-17822014000400302\&lng=en. https://doi. org/10.1590/2317-1782/201420130044.

12. Balen SA, Bretzke L, Mottecy C, Liebel G, Boeno MRM, Gondim LMA. Temporal resolution in children: comparing normal hearing, conductive hearing loss and auditory processing disorder. Rev. Bras. Otorrinolaringol. [journal on the internet]. 2009 [accessed on 2017 Mar 27]; 75(1):123-9. Available at: $\quad$ http://www.scielo.br/scielo.php?script $=$ sci_ arttext\&pid=S0034-72992009000100020\&lng =en.

13. Zaidan E, Garcia AP, Tedesco ML, Baran JA. ADOLEC-Desempenho de adultos jovens normais em dois testes de resolução temporal. Pró-Fono R. Atual. Cient. [journal on the internet]. 2008 [accessed on 2017 Apr 11]; 20(1):19-24. Available at: $\quad$ http://www.scielo.br/scielo.php?script $=$ sci_ arttext\&pid = S0104-56872008000100004\&Ing=en. https://doi.org/10.1590/s0104-56872008000100004.

14. Gonçalves IC. Aspectos Audiológicos da gagueira: evidências comportamentais e eletrofisiológicas [Dissertação]. São Paulo (SP): Faculdade de Medicina, Universidade de São Paulo; 2013.

15. Bohnen AJ. Estudo das palavras gaguejadas por crianças e adultos: caracterizando a gagueira como um distúrbio de linguagem [Dissertação]. Porto Alegre (RS): Universidade Federal do Rio Grande do Sul; 2009.

16. Beal DS, Gracco VL, Lafaille SJ, Luc F. Voxel-based morphometry of auditory and speech-related cortex in stutterers. NeuroReport. 2007;18(12):1257-60.

17. Chang SE, Erickson KI, Ambrose NG, HasegawaJohnson MA, Ludlow CL. Brain anatomy differences in childhood stuttering. Neuroimage. [journal on the internet]. 2008 [accessed on 2017 Apr 29]; 39(3):1333-44. Available at: https:// www.sciencedirect.com/science/article/abs/ pii/S1053811907008944. https://doi.org/10.1016/j. neuroimage.2007.09.067.

18. Kell CA, Neumann K, Von Kriegstein K, Posenenske C, Von Gudenberg AW, Euler H et al. How the brain repairs stuttering. Brain. 2009;132(10):2747-60.
19. Kikuchi Y, Ogata K, Umesaki T, Yoshiura T, Kenjo $M$, Hirano $Y$ et al. Spatiotemporal signatures of an abnormal auditory system in stuttering. Neuroimage. [journal on the internet]. 2011[accessed on 2017 Mar 14]; 55(3):891-9. Available at: https://www. ncbi.nlm.nih.gov/pubmed/21232617. https://doi. org/10.1016/j.neuroimage.2010.12.083.

20. Pereira LD, Schochat E. Testes auditivos comportamentais. In: Pereira LD, Schochat E, editors. Testes auditivos comportamentais para avaliação do processamento auditivo central. São Paulo: Pró-Fono. 2011. p.11-4.

21. Weihing JA, Musiek FE, Shinn JB. The effect of presentation level on the Gaps-In-Noise (GIN) test. J Am Acad Audiol. 2007;18(2):141-50.

22. Assis EF, Parreira LMMV, Lodi DF. Noise Test: GAP detection in children with phonological deviation. Rev. CEFAC [journal on the internet]. 2013 [accessed on 2017 Nov 23]; 15(1):79-88. Available at: $\quad$ http://www.scielo.br/scielo.php?script $=$ sci arttext\&pid =S1516-18462013000100009\&Ing=en. Epub Apr 05, 2012. https://doi.org/10.1590/ S1516-18462012005000029.

23. Keith RW. Random gap detection test. St. Louis, MO: Auditec. 2000.

24. Musiek FE. Frequency (pitch) and duration pattern tests. J Am AcadAudiol. 1994;(5):265-8.

25. Nazaré CJ. Testes temporais para estudo do processamento auditivo central. [Thesis]. Porto (PT): Faculdade de Engenharia, Universidade do Porto; 2009.

26. ALM PA. On the causal mechanisms of stuttering. Lund, Sweden: Lund University, 2005.

27. Smith NA, Trainor LJ, Shore DI. The development of temporal resolution: between-channel gap detection in infants and adults. J Speech Lang Hear Res. 2006;49(5):1104-13.

28. Galvão TF, Pansani TSA, Harrad D. Principais itens para relatar revisões sistemáticas e meta-análises: a recomendação PRISMA. Epidemiologia e Serviços de Saúde. [journal on the internet]. 2015 [accessed on 2017 Nov 23]; 24:335-42. Available at: https://www.scielosp.org/article/ ress/2015.v24n2/335-342/pt/. https://doi.org/10.5123 /S1679-49742015000200017.

29. Marcília LF. Fundamentos em Processamento Auditivo. Profala. [Homepage on the Internet]. 2016 [accessed on 2017 Apr 29]. Available at: http:// www.profala.com/artaudio6.htm. 
30. Luria AR. El cérebro em accíon. In: Marcília LF, editor. Fundamentos em Processamento Auditivo. Profala. [journal on the internet]. 2016 [accessed on 2017 Apr 29]. Available at: http://www.profala. com/artaudio6.htm.

31. Pickless IO. Physiology of the cerebral auditory system. In: Pinheiro ML, Musiek FE, editors. Assessment of central auditory dysfunction: Foundations and clinical correlates. Baltimore: Williams \& Wilkins; 1985. p. 67-86.

32. Samelli AG. O Teste GIN (Gap in noise): limiares de detecção de gap em adultos com audição normal [Dissertation]. São Paulo (SP): Faculdade de Medicina, Universidade de São Paulo; 2005.

33. Malta MM, Cardoso LO, Bastos FI, Magnanini MMF, Silva CMFP. Iniciativa STROBE: subsídios para a comunicação de estudos observacionais. Rev. Saúde Pública [journal on the internet]. 2010 [accessed on $2017 \mathrm{Nov}$ 27]; 44(3):559-65. Available at: http://www. scielo.br/scielo.php?script $=$ sci_arttext $\&$ pid $=$ S0034-89102010000300021\&lng=en. http://dx.doi. org/10.1590/S0034-89102010000300021.

34. Martins JS, Pinheiro MMC, Blasi HF. A utilização de um software infantil na terapia fonoaudiológica de Distúrbio do Processamento Auditivo Central. Rev. soc. bras. fonoaudiol. [journal on the internet]. 2008 [accessed on 2017 Apr 29]; 13(4):398-404. Available at: http://www.scielo. $\mathrm{br} /$ scielo. php? script $=$ sci_arttext \& pid $=$ S1516$80342008000400016 \&$ lng =en. http://dx.doi. org/10.1590/S1516-80342008000400016.

35. Giraud AL, Neumann K, Bachoud-Levi AC, Von Gudenberg AW, Euler HA, Lanfermann $\mathrm{H}$ et al. Severity of dysfluency correlates with basal ganglia activity in persistent developmental stuttering. Brain. 2008;104(2):190-9. https://doi.org/10.1016/j. bandl.2007.04.005.

36. Amaral MIR, Martins PMF, Colella-Santos MF. Temporal resolution: assessment procedures and parameters for school-aged children. Braz. j. otorhinolaryngol. [journal on the internet]. 2013 [accessed on 2017 Apr 11]; 79(3):317-24. Available at: $\quad$ http://www.scielo.br/scielo.php?script $=$ sci_ arttext\&pid=S1808-86942013000300010\&Ing =en. http://dx.doi.org/10.5935/1808-8694.20130057.
37. Liporaci FD, Frota SMMC. Envelhecimento e ordenação auditiva temporal. Rev. CEFAC [journal on the internet]. 2010 [accessed on $2017 \mathrm{Dec}$ 7]; 12(5):741-8. Available at: http://www.scielo. $\mathrm{br} / \mathrm{scielo}$. php? script $=$ sci_arttext $\&$ pid $=$ S151618462010000500004\&lng=en. Epub em 30 de julho de 2010. http://dx.doi.org/10.1590/ S1516-18462010005000078. 